\title{
Bahçıvan Devletin Ayrık Otları: Moriskolar -Son Savunma-
}

\author{
Feridun BILGIN*
}

Gardener State's Quitchgrass: Moors -Last Defense-

Citation/C): Bilgin, Feridun, (2015). Gardener State's Quitchgrass: Moors - Last Defense-, Milel ve Nihal, 12 (1), 107-126.

Abstract: XVIth century Spanish religious and administrative environment who has put an end to the military and political presence of Andalusian Muslims (Nuevos Cristianos de Moros) has banned and declared war to every icon, every sign and every color of Islam and its culture carried by Muslims. Andalusian Muslims had tried to protect their presences through sometimes rebelling or sometimes bowing to pressures but usually engaging in "deception". Don Francisco Núñez Muley who is one of worthy Moors has given a memorial, which reflects the mood of the defeated, to Granada's Spanish administrator. Although this memorial was based on historical, social and political strong arguments. Nevertheless, it could not change the "judgement" of the fate about Moors. They would lose their native language, clothing, customs and traditions, and finally they would be exiled all together from their homeland (Andalusia).

Key Words: Andalusian, Moors, 1567 decree, Don Francisco Núñez Muley, Memorial, Assimilation.

Atıf/C: Bilgin, Feridun, (2015). Bahçıvan Devletin Ayrık Otları: Moriskolar -Son Savunma-, Milel ve Nihal, 12 (1), 107-126.

* Yard. Doç. Dr., Mardin Artuklu Üniversitesi, Edebiyat Fakültesi, Tarih Bölümü [feridunb@gmail.com] 
Öz: XVI. asır İspanyol dinî ve idarî çevreleri, askerî ve siyasî varlıklarına son verdikleri Endülüs Müslümanlarının (Nuevos Cristianos de Moros) taşıdıklarını düşündükleri İslâm'a ve onun kültürüne ait her simgeye, her işarete ve her renge savaş açmış ve yasaklamıştır. Endülüs Müslümanları ise, baskılara karşı, her defasında, bazen isyan ederek, bazen boyun eğerek, fakat çoğu zaman "takiyye" yaparak varlıklarını korumaya çalışmışlardır. Moriskolar'ın ileri gelenlerinden biri olan Don Francisco Núñez Muley'in, Gırnata'nın İspanyol yöneticisine verdiği ve mağlupların ruh halini yansıtan ihtarnâme/memorial, tarihsel, sosyal ve siyasal olarak güçlü argümanlara dayanmaktadır Buna rağmen, Moriskolar hakkında kaderin verdiği "hükmü" değiştirmeye yetmeyecektir. Ana dillerini, giyim-kuşamlarını, örf ve adetlerini kaybedecek ve son olarak da yurtlarından (Endülüs) topluca sürgün edileceklerdir.

Anahtar Kelimeler: Endülüs, Moriskolar, 1567 fermanı, Don Francisco Núñez Muley, Memorial, Asimilasyon.

\section{Giriş}

XVI. asrın ikinci yarısını, Endülüs Müslümanları'nın (Moriskolar) ${ }^{1}$ İspanya'daki varlıkları için yeni bir dönemin başlangıcı olarak değerlendirmek gerekmektedir. Bu döneme kadar, ne İspanyol yönetimi tarafından çıkarılan fermanlar ne de Engizisyon Mahkemesinin gözetim ve denetim çalışmaları "tatmin" edici bir sonuca ulaşamamıştır. Moriskolar' 1n "gerçek birer Hıristiyan (Katolik)" olmaları konusunda yönetim kademelerinin gösterdiği tüm çabalar, Moriskolar için zorunlu olan sürekli bir "takiyye" süreciyle sonuçlanmıştır.

MMoriskolar, Katolik Krallar (Fernando ve İzabella) ile Grrnata'nın (Granada) son emîri Ebû Abdullah arasında imzalanan anlaşmanın ${ }^{2}$ aksine baskı ve şiddet uygulanarak din değiştirmeye zorlanmışlardır. Bu baskı, İspanyol yöneticilerinin Moriskolar'ın mensup oldukları dinin (İslam'ın) ve bu dinden kaynaklandığına

1 Morisko (Morisco): Endülüs'te, Hıristiyan hâkimiyetinde yaşayan ve baskıyla din değiştirmek zorunda kalan Endülüs Müslümanları'na verilen isim, geniş bilgi için bkz. Mehmet Özdemir, “Moriskolar", DİA, XXX, İstanbul, 2005, s. 288291.

2 Gırnata'nın teslim anlaşmasıyla ilgili geniş bilgi için bk. Antonio Gallego Burín Alfonso Gâmir Sandoval, Los moriscos del reino de Granada según el Sínodo de Guadix de 1554, Universidad de Granada, Granada 1996, s.XXXV; Gırnata Teslim anlaşması için bkz. L. P. Harvey, “Capitulations of Granada”, çev.: Teofilo Ruiz, (Ed. Medieval İberia, Olivia Remie Constable), Philadelphia: 1997, s. 344-350; Feridun Bilgin, Nasrîler (Benî Ahmer) Sonrasında Endülüs'teki Müslümanlar (Moriskolar), Yayımlanmamış Doktora Tezi, Marmara Üniversitesi Sosyal Bilimler Enstitüsü, İstanbul 2010, s.51-54. 
inanılan örf ve adetlerin yeni dine (Katolik) adaptasyonları konusunda ciddî bir engel teşkil ettiklerine dair olan inançtan ${ }^{3}$ kaynaklanmıştır. Bu inanç doğrultusunda Kraliçe Doña Juana (Fernando'nun kız kardeşi) döneminde (1504-1516) Moriskolar'ın kılık ve kıyâfetlerinin yasaklanmasıyla ilgili bir kanûn çıkarılmıştır (1508). Fakat bu kanûn, İspanyol yönetim kademelerinin aynı fikirde bulunmaması sebebiyle askıda kalmış, uygulanamamıştır ${ }^{4}$. Benzer bir girişim İmparator Şarlken (V. Charles, İsp. Carlos Quinto) döneminde (1516-1556) yeniden gündeme gelmiş, Moriskolar'ın sosyo-kültürel yaşamlarıyla yapılan araştırmanın sonuç kısmında buğday tarlasında kısa sürede temizlenmesi imkânsız "yabani otlara" ya da "sapkınlık budaklarıla dolu pörsümüş ă̆açlara"5 benzetilen Moriskolar için yeni yaptırımlara başvurulması tavsiye edilmiştir. Şarlken gerek devlet adamlarının gerekse kilise çevrelerinin telkinleriyle 1526 ' da Moriskolar' $n$ örf ve âdetlerini yasaklayıcı bir kanûn hazırlamıştır (1526) ${ }^{6}$. Fakat, bu kanûn, Moriskolar'ın Şarlken'e 80.000 duka altın rüşvet olarak vermesiyle 40 yıl ertelenmiştir7. İspanyol devletinin içerisinde bulunduğu malî sorunlar ve devam eden bir takım yatırımlar için finansman sorunu, Şarlken'i Moriskolar'ın teklifini kabul etmeye mecbur bırakmıştı. Daha öncesinde, Ciudad de Real'de bulunan Yüksek Mahkeme'nin (Audencia y Chancillería) (1505'de) ve Jean'da bulunan Engizisyon Mahkemesi'nin (1526'da) Girnata'ya transferleri, İspanyol yönetiminin

3 Mercedes Garcîa Arenal, Los Moriscos, Universidad ve Granada, Granada 1996, s.47

4 Burín y Sandoval, age, s.XXXV-XXXVI; Jose Maria Martin Ruiz, "Politica y Moral en El Siglo de Oro: El Memorial del Morisco Francisco Nuñez Muley", Baetica. Estudios de Arte, Geografía e Historia, 17 (1995), s.392.

5 Matthew Carry, Kan ve İman, trc.: Regaip Minareci, Alfa Yayınları, İstanbul 2015, s.336.

6 1526' da çıkarılan ve 40 yıl süreyle ertelenen kanûnda kısaca şu hususlara yer verilmiştir; Arapça'nın konuşulması, Mağribiler'e has elbiselerin dikilmesi ve giyilmesi, Müslüman ebelerin doğumları yaptırması, kadınların ellerine, ayaklarına ve başlarına kına yakmaları, Mağribi isimlerin kullanılması yasaklanmış, hamamların kapatılması emredilmişti, bkz. Jaime Bleda, Coronica de Los Moriscos de España, Valencia: Universitad de Valencia, 2001, s. 65; H.Charles Lea, İspanya Müslümanları Hıristiyanlaştırılmaları ve Sürülmeleri, çev.: Abdullah Davudoğlu, İnkılap Yayınları, İstanbul 2006, s.212-213; Bilgin, age, s.76-77.

7 Carlos Javier Garrido Garícia, “Colaboracionismo Mudéjar-Morisco en el Reino de Granada. El caso de la Diócesis de Guadix: Los Abenaxara (1489-1580)", MEAH, Seccíon Árabe-Islam, 48 (1999), s.127; Carlos, Moriskolar'ın ödediği paraların bir kısmını Elhamra Saray kompleksi içinde yaptırdığı Rönesans Sarayı'nı inşâ etmek için kullanımıştı, bk. Carr, age, s.128. 
Moriskolar'a karşı sert tedbirlerin alınacağının habercisi olmuş8, peşpeşe bir takım yaptırım kanûnları çıkarılmıştır. Moriskolar tarafından "şeytanın mahkemeleri" olarak isimlendirilen Engizisyon mahkemelerinin Moriskolar'ın asimilasyon sürecinde önemli işlevleri olacaktır; bu mahkemelerin eline düşme korkusu, Moriskolar'ın bireysel ve toplumsal psikolojilerini olumsuz etkileyecektir.

İktidarların düzen inşası, yabancılara ve yabancı olana karşı yürütülen bir aşındırma savaşı olarak okunabilir. Zygmunt Bauman, bahçe metaforu üzerinden devletlerin/iktidarların adeta bir bahç1van edasıyla bahçedeki ayrık otları bertaraf etme adına yürüttüğü bu savaşta birbirinini tamamlayan iki strateji kullandıklarını belirtir. Bunlardan ilki antropofajik'tir; yabanciları yutarak ve ardından da bunları metabolik olarak kişinin kendisinden ayırt edilemez bir doku haline dönüştürerek yok etmek. Bu asimilasyon stratejisidir; farklıyı benzer kılma, kültürel ya da dilsel ayrımları yumuşatmak, yeni ve her şeyi kuşatan düzene uyumluluğu besleyenler dışında tüm gelenekler ve bağlılıkları yasaklamak, sadece tek bir uyumluluk ölçütünü dayatmak ki Moriskolar'a uygulanan bu ilk strateji yeterli sonuç üretememiştir. İktidarın uyguladığı ikincisi asimilasyon stratejisi ise; antropoemik'tir; yabancıları kusmak, onları düzenli dünyanın sınırları dışına itmek/sürmek ve bunlarla iletişimi tümden kesmek. Bu yabancıları gettoların (Moriskolar için morerías) görünür duvarlarının içine ya da görünmeyen fakat en az bu duvarlar kadar somut olan birlikte yemek yeme, evlilik ve ticâret yasaklarının dışına hapsetmek. Özetle, temizlenmesi mümkün olmayanları toprakların dişına süren dışlanma stratejisinden bahsetmek gerekmektedir. ${ }^{9}$

Toplumsal dışlama stratejisi ile birlikte çıkarılan yeni kanûnî yaptırımlar sosyal evrene kimin dahil edileceğini (inside) kimin bu evrenden dışlanacağını (outside) belirler. Nitekim yürürlüğü ertelenen kanûnun yeniden gündeme getirilmesi için dönemin Grrnata Başpiskoposu Don Gaspar de Avalos hareket geçmiş ve ona destek veren din adamları şehir meydanında bu yasakları açıç̧a ilan etmişlerdir (1540). Fakat, bu girişim Girnata Şehir Meclisi'nde bulunan üyelerin, Belediye Meclis Başkanı'nın ve Mondejar Markizi'nin

8 Leonard Patrick Harvey, Muslims in Spain, 1500 to 1614, The University of Chicago Press, London, 2005, s.206; Carr, age, s.199.

9 Zgmunt Bauman, Postmodernlik ve Hoşnutsuzlukları, Çev.: İsmail Türkmen, Ayrintı Yayınları, İstanbul 2013, s. 32. 
karşı çıkması nedeniyle sonuçsuz kalmıştır. Guéjar kasabasında çarşaf ve Mağribî dansının yasaklanma girişimi de aynı şekilde akîm kalmıştır. ${ }^{10}$

Kral Şarlken 1555 'de İspanya tahtını oğlu II. Philip'e (kâfirlerin çekici) ${ }^{11}$ bırakırken ondan; engizisyonu desteklemesini, sapkınlara karşı savaşmasını ve Mağribileri (Moriskoları) ülkeden kovmasını istemişti ${ }^{12}$. Kral Philip babasının yılmaz takipçisi olduğunu 1564 ' de Papa IV. Pius'a gönderdiği bir mektupla göstermiştir. Philip mektubunda; “Tanrı' nın hakiki dinene en ufak bir zarar vereceğime bütün devletlerimi kaybetmeyi, elimden gelseydi hayatımı yüz defa feda etmeyi tercih ederim. Çünkü ben, sapkınların hükümdarı değilim ve asla da olmayacağımı." diyerek babasının vasiyetine bağlılığını ortaya koymuştur. ${ }^{13}$

Kasım 1566'da İspanya'nın kan ve iman arılı̆̆ında olması gerektiğini düşünen II.Philip'in talimatıyla dönemin Engizisyon Genel Başkanı Diego de Espinosa (1566-1572) 1526'da Şarlken tarafından ertelenen kanûn maddelerini ve bunlara ilâveten yeni yasakları içeren yeni bir kanûn metni hazırladi ${ }^{14}$. Moriskolar'ın toplumsal görünürlüklerini tamamiyle ortadan kaldırmayı amaçlayan bu kanûnun çıkarılması Kral Philip'in "Tanrının sesini dinlediğine" ikna olmasının sonucuydu ${ }^{15}$. Söz konusu kanûn metni (La Nueva Premática) 1 Ocak 1567'de Kraliyet Anayasa Mahkemesi ve Girnata Yüksek Mahkemesi'nin başkanı Pedro de Deza Manuel (1520-1600) tarafından Gırnata başta olmak üzere bağlı bütün bölgelerde ilan edildi ${ }^{16}$. Moriskolar fermanı erteletmek için yaklaşık bir yıl süren neticesiz görüşmeler yaptıktan sonra isyan ettiler ${ }^{17}$. Bu çalışmada, Moriskolar'ın toplumsal görünürlüklerini ortadan kaldıran, sosyokültürel ve dini yaşamlarını doğrudan etkileyen 1567 fermanına karşı İspanyol resmi çevrelerinde yürüttükleri diplomasi ele alınacaktır. Bilhassa, Don Francisco Núñez Muley'in Moriskolar adına Gırnata meclis başkanına verdiği ihtarnâme (memorial) üzerinde durulacaktır.

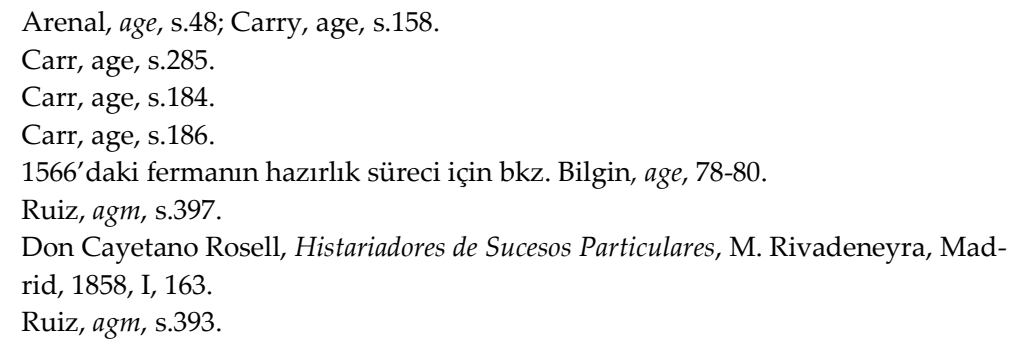




\section{Don Francisco Núñez Muley: Bilge Şahsiyet}

Moriskolar'ın 1567 tarihli fermanı ertelemek maksadıyla harekete geçtiklerini ifade eden dönemin İspanyol yazarı Mármol, öncelikle, Baeza' daki İspanyol yargıcına müracaat ettiklerini fakat, sonuç alamadıklarını, sonrasında ise başkent Madrid'e gitmeden evvel, Gırnata Meclis Başkanı Pedro de Deza'ya gittiklerini kaydeder. Moriskolar'ın asıl amacı fermanın tümden yürürlüğünü durdurmaktı, bunu başaramazlarsa, en azından uygulanmasını yumuşatmakt ${ }^{18}$. Bu amaçla içlerinde, diplomasi konusunda en tecrübeli ve Hıristiyan yöneticilerle kurduğu diyaloglar konusunda en yetkin, herkes tarafından saygın olarak bilinen ve bazı modern araştırmacılar tarafından "işbirlikçi" olarak isimlendirilen ${ }^{19}$ birisini, Don Francisco Núñez Muley'i temsilci olarak seçtiler.

Don Francisco Núñez Muley ${ }^{20}$, küçük yaşlarda, Gırnata'nın ilk piskoposu olan Hernando de Talavera'nın (1428-1507) yanında yar-

18 Javier Castillo Fernández, La Historiografía Española del Siglo XVI: Luis del Mármol Carvajal y Su Historia del Rebelión y Castigo de Los Moriscos del Reino de Granada. Análisis Histórico y Estudio Crítico, Editorial de la Universidad de Granada, Granada 2014, s.621.

19 Harvey, Muslims in Spain, s.211.

20 Anne tarafından Gırnata' nın son Müslüman yöneticilerinin neslinden gelen Don Francisco Núñez Muley (1492-1570), seçkin bir kimse olarak, tahminen 1500'de din değiştirip Hıristiyan olmuştu. Onun din değiştirmeyi gönüllü yapıp yapmadığı net değildir. Muley'in yeğeni olan Hernando Muley, Fas'da hüküm sürmüş kraliyet ailesinden geldiklerini-o soya mensup oldukların- belirtmektedir. Muley'in amcası olan Don Hernando de Fez ise iki bağ ile kraliyet ailesine mensuptu; onun karısı Gırnata'nın son sultanı Ebû Abdullah'ın kız kardeşi idi, Gırnata Hıristiyanlar tarafından kuşatıldığında (1491) Ebû Abdullah'ın kız kardeşiyle evlenmişti. Ayrıca, Kuzey Afrika'daki Meriniler'in yıkılışından (1465'de) sonra onların itibar ettiği bir kimse olarak Gırnata'ya ulaşmıştı. Hristiyan yönetimindeki Gırnata'da Francisco Núñez Muley'e Alhamrâ sarayının gelir-gider durumuna bakması sebebiyle yıllık 9.000 marevidî ödeniyordu. Onun bu sosyal, politik ve ekonomik ayrıcalıkları, Nasrî hanedan ailesine mensup olması sebebiyleydi. Büyük Gırnata Savaşı (1568-1570) sonrasında gerçekleşen sürgünler s1rasında muhtemelen hayatını kaybetmiş olmalıdır. Pedro de Deza'ya, Moriskolar'ın ihtâr mektubunu (Memoria) ilettiğinde 70 yaşlarındaydı. bkz. Míkel de Epalza, “La Voz Oficíal De Los Musulmanes Hispanos, Mudejares y Moriscos, A Sus Autorıdades Cristianas: Cuatro Textos, En Árabe, En Castellano Y En Catalán-Valenciano", Sharq al-Andalus, 12 (1995), s.295; Francisco Núñez Muley, A Memorial for the President of the Royal Audiencia and Chancery Court of he City and Kingdom of Granada, Ed. and Transl.: Vincent Barletta, Chicago 2007, s.4; s.8-9. 
dımcı olarak 3 yıldan fazla bir süre bulunmuş, şövalye eğitimi almıştı. 1513'de Girnata'l1 bir delegasyonla birlikte (bu sırada delegasyonun en küçük üyesiydi ${ }^{21}$ ) Kral Fernando ile görüşmüştü. 1518'de Muley, bu sefer Conde de Tendilla (Markez de Mondejar) ile birlikte, İspanya'nın yeni kralına (Şarlken'e) Moriskolar'ın vergilerini takdim, hem de, Moriskolar'ın giyimlerini yasaklayan kanûnu ertelemek için kralın huzuruna çıkmış ve bu amacına ulaşma konusunda muvaffak olmuştu ${ }^{22}$. 1523 ve $1559^{\prime}$ da da benzer görevlerle İspanyol kralıyla görüşmeler yapmışt1 ${ }^{23}$.

İspanyol yöneticileri nezdinde hatırı sayılır bir kimse olan $\mathrm{Mu}$ ley, oğlu Alonso Martínez de Santiago'yu kral adına toplanan Farda ${ }^{24}$ vergisini toplamakla görevlendirmişti. Toplanan bu vergilerden Muley ailesinin geliri yıllık 9.000 marevidi idi. Moriskolar arasında sosyo-ekonomik ve siyasî pozisyonu sebebiyle itibar görüyordu. Muley soyismi, Girnata kraliyet ailesinden gelenlere verilmekteydi ${ }^{25}$.

\section{Memorial: Son Savunma}

İspanyol kaynaklarında "Memorial" 26 olarak geçen ve geniş bir özeti dönemin İspanyol yazarlarından biri olan Mármol'un eserinde yer alan Muley'in Pedro de Deza'ya hem sözlü hem de yazılı olarak verdiği mektup/ihtarnâme ${ }^{27}$, Moriskolar'ın İspanyol yönetimine bak1şıyla ilgili yaklaşımlarını yansıtması açısından önemlidir.

21 Burín y Sandoval, age, s.XXXVI; Harvey, Muslims in Spain, s.211.

22 Burín y Sandoval, age, s.XXXVI; Joaquin G1l Sanjuan, Presion Material Sobre Los Moriscos Andaluces, Baetica. Estudios de Arte, Geografía e Historia, 3 (1980), s.189.

23 Harvey, Muslims in Spain, s.212.

24 Farda: Hıristiyan krallıklarında Moriskolar ve Yahudiler tarafından ödenen kıyı bölgesinin savunması için verilen vergi çeşididir,

bkz. http://lema.rae.es/drae/?val=farda (25.03.2015); Carry, age, s.156; Genellikle yılda bir ödenen farda vergisi 1563 ' da toplam 20 bin duka altına ulaşmıştı, bk. S.Muhammed İmamüddin, Endülüs Siyasi Tarihi, terc.: Yusuf Yazar, Rehber Yayıncilik, Ankara 1990, s.356; Lea, age, s.214.

25 M.a Jesús Rubiera Mata, “La Familia Morisca de Los Muley-Fez, Príncipes Meriníes e Infantes de Granada", Sharq al-Andalus, 13 (1996), s.159-160.

26 Bkz. Fernández, age, 620, dn. 512; Antonio Gallego Burín -Alfonso Gâmir Sandoval , Los Moriscos del Reino de Granada Según el Sínodo de Guadix de 1554, Granada: Universidad de Granada: 1996, s.XXXV.

27 Memorial'ın asıl kopyalarından biri, XVIII. asrın ikinci yarısında Elhamrâ'da görevli olan Lorenzo Núñez de Prado tarafından Elhamrâ arşivinde bulunmuştur. Bu kopya, bazı yanlışlar ve eklerle birlikte Rafael Contreras tarafından yayımlanmıştır. Daha sonraları Biblioteca Nacional de Madrid'de bulunan başka bir orijinal nüshası, Raymond Foulché-Delbosc tarafından yayımlanmış ve Antonio 
Memorialda yer alan ve eleştiri konusu yapılan hususlar dikkatle incelendiğinde yeni fermanın Moriskolar'ın dinî ve sosyo-kültürel yaşamlarını tümden ortadan kaldırmaya matuf olduğunu göstermektedir. İspanyol yönetimi, daha öncesinde İspanya' da bulunan dinî gruplardan biri olan Yahudileri fazla zorlanmadan, herhangi bir mukâvemetle karşılaşmadan kolay bir şekilde asimile etmiş, din değiştirmelerini sağlamıştı. Fakat, Moriskolar'ın Yahudiler'den farkı, silahlı olmaları ve ülke dışından yardım alma imkanına sahip olmalarıyd $1^{28}$. Dolayısıyla, Moriskolar'ın asimilasyonu meselesi hem uzun bir sürece yayılmış, hem de, Katolik İspanyol devletinin maddî ve manevî gücünü azaltan bir etken olarak on yıllarca varlığını devam ettirdi.

Francisco Núñez Muley, Pedro de Deza'nın huzurunda, saygida kusur etmeyen, alçak bir ses tonuyla başlayan konuşmasında hem Tanrı'nın hem de İspanya kralının hizmetinde olduğunu (He servido a Dios nuestro señor y a la corona real..." ifade etmiştir. Moriskolar'la İspanyol yönetimi arasında, yaşadığı döneme kadar meydana gelen olumsuz hadiseleri sebep ve sonuçlarıyla özetledikten sonra, Katolik devletin dinî kültürünü düzenleyen yeni kanûnda ( $L a$ nueva premática) yer alan emir ve yasakların Girnata ve civâr bölgelerinde yaşayan Moriskolar'ı aşırı derecede rahatsız ettiğini açıklamaya çalışmıştır. Bunu yaparken de Katolik öğretilerine karşı gelmeden, İspanyol devletinin sadık bir hizmetkârı olduğunu sık sık ifade ederek, Moriskolar'ın yaptıkları ve yeni kanûnda yasaklanan her ne varsa bunların kültürel, ekonomik ve temizlik gibi ihtiyaçlardan kaynaklandığını isbata gayret etmiştir ${ }^{29}$. Muley, Memorialda anlattığı olayları güçlü argümanlarla desteklemiştir ${ }^{30}$.

Memorialda yer verilen hadiselerden biri olan Girnata isyanları (1499, 1500, 1501), Muley'e göre, dönemin İspanya kralına ve krall1ğına karşı değil, Katolik Kralların (İzabella ve Fernando) imzalarının yer aldığı Gırnata teslim anlaşmasının ihlâl edilmesine, yani,

\footnotetext{
Gallego Burín ve Alfonso Gámır Sandoval ise Raymond'un bu çalışmasını Moriskolar'la ilgili yazdıkları kitabın girişine almışlardır. Bkz. Contreras Y Muñoz, Rafael, "Nuevos datos sobre la guerra y la expulsión de los moros", Revista de España, LXVIII (1879): 185-209; Foulché-Delbosc, Raymond, “Memorial de Francisco Núñez Muley", Revue Hispanique, Paris, VI (1899): 205-239; Burín y Sandoval, age, s.XXXVI-LII.

28 Ruiz, agm, s.397.

29 Ruiz, agm, s.395-398.

30 Contreras, agm, 188.
} 
Katolik Kralların imzaladığı bu metne sadık kalmayan yöneticilere karşı çıkarılmışlardı ${ }^{31}$. Yine, Şarlken döneminde çıkan Comunero isyanında (1520) Moriskolar'ın Katolik Kral tarafında nasıl canlabaşla yer aldıklarının altını çizer. Sözkonusu isyan sırasında, Mondejar Markizi, Don Antonio, Don Bernandino de Mendoza ve onun kardeşleri ile Moriskolar'dan oluşan 400'den fazla askerle tüm İspanya'da Comuneroslar'a karşı ilk silahlanan insanlar olduklarını belirterek, Don Hernando de Cordova, Diego Lopez Aben Axar, Diego Lopez Harera gibi komutanlar ile Girnata'nın son sultanı Ebû Abdullah'ın kardeşi olan Don Juan de Granada'nın ${ }^{32}$ kraliyet ordusunda bir kahraman olarak yer aldığını ve İspanya kralına sadakatle bağlı olduğunu ifade etmiştir. ${ }^{33}$ Muley, Moriskolar'ın devletin "sadık teb'aları" olduklarını kanıtlamak amaciyla tarihî şahsiyetleri referans olarak kullanmıştır.

Memorialda Moriskolar'ın dil, giyim-kuşam, örf ve adetleri olmak üzere 3 temel sorun ele alınmakta ve bunlara dair açıklamalara yer verilmektedir. Daha sonra da görüleceği gibi tüm sorunlar dinî alanının dışına çıkarılarak son derece rasyonel bir zeminde tartışılmaktadır. Çünkü Muley, getirilen yasakların ve ortadan kaldırılmaya çalışılan unsurların, İspanyol yönetimi tarafından "İslam $\hat{\imath}$ " olarak kodlandığının farkındaydı ve bu sebeple daha yerel ve daha dünyevî bir dil kullanma zorunluluğu duymuştu.

Memorialda üzerinde durulan en önemli ve Moriskolar'ın canını en fazla sıkan yasağın "Arapça" diliyle her türlü yazılı ve sözlü iletişimin yasaklanmasıydı. Aslında, Arapça'nın kullanılması ve halkın ticarî amaçlı faaliyetlerinde (senet, tapu vs...) kullanımı

31 Burín y Sandoval, age, s.XXXV.

32 Gırnata'nın son sultanı Ebû Abdullah'ın üvey kardeşleri olan Nâsır b. Ali ve kardeşi din değiştirip Hıristiyan olmuş, Nâsır, Fernando de Granada, kardeşi ise Don Juan de Granada adını almıştır. Babaları Ebû'l-Hasan Ali'nin ikinci eşi İsabel de Solis'in (bu kadın Müslüman olunda Zoraya/Süreyya ismini aldı) oğullarıydı. Genç yaşta Hıristiyan olan kardeşlerden Don Juan de Granada Galicia' da yönetimde bulunmuştu, bkz. Mehmet Özdemir, Endülüs Müslümanları (siyasî tarih), 2012, s.275; s.75, dn. 47.

33 Arenal, Los Moriscos, s.51; Early Modern Spain, Ed.: Jon Cowans, University of Pennsylvania, Philadelphia 2003, 107; 219; Lea, age, s.211. 
1526'da yayımlanan fakat, uygulanmayan kraliyet fermanıyda yasaklanmışt ${ }^{34}$. Yeni fermanda ise; Arapça ile yapılan bütün mükâvelelerin (yapılmış olan kontrat ve yazışmalar) geçersiz sayılacağı, Arapça yazılmış olan bütün kitapların 30 gün içerisinde Gırnata Meclis Başkanı Deza'ya teslimi, 3 yıl içerisinde Gırnata ve civâr bölgelerinde yaşayan herkesin Kastilya dilini öğrenmeleri, 3 yıl sonrasında hiç kimsenin gizlice ve alenen Arapça konuşmasına izin verilmeyeceği ilan edilmiştir ${ }^{35}$.

İspanyol yönetimi (XVI. asırda) Arapça dilini temizlik, yemek, adet ve göreneklerle ilgili değil, İslâm dinine bağlılığın bir işareti olarak değerlendirmiştir ${ }^{36}$. Aslında, Arapça'yla ilgili yasak, erken dönemde başlamıştı; 1502' de çıkarılan bir fermanda Yeni Hıristiyanların (cristianos nuevos) ${ }^{37}$, dinî ibâdetlerini Arapça ile değil, Kastilyanca ve Latince ile yapmaları emredilmişti ${ }^{38}$. Gırnata Şehir Konseyi de Arapça konuşulmasını her türlü kötüğün kaynağı olarak değerlendirmiş, "Moriskolar'ın hayatında var olan kargaşanın" temel sebebi ve Moriskolar'in Hiristiyan toplumuna entegrasyonun önendeki en büyük engel olduğuna inanmıştır ${ }^{39}$. Yine, Moriskolar'ın kendi aralarında Arapça konuştuklarını duymaları, komşuları olan Hıristiyanlar için ciddi anlamda rahatsız edici bir toplumsal problemdi ${ }^{40}$.

Muley, Gırnata ve çevresinde Arapça'nın konuşulmasının İslâm dinine bağlılıkla ilgisi olmadığını mantıksal bir çerçevede izâh ederek sakıncalı olmadığını göstermeye çalışmıştır; Kudüs ve Malta'daki Katolik Hıristiyanların Arapça'yı hem konuştuklarını

34

Luis de Mármol Carvajal, Historia de Rebellion y Castigo de los Moriscos del Reino de Granada, I-II, Madrid 1797, I, 141-142; Jaime Bleda, Coronica de Los Moriscos de España, Universitad de Valencia, Valencia 2001, s. 656.

35 Bilgin, age, s.81-82.

36 Mercedes García Arenal, "The Religious Identity of the Arabic Language and he Affair of the Lead Books of the Sacromonte of Granada", Arabica, 56 (2009), s.498.

Cristianos Nuevos: "Cristiano Nuevo" kavramı Hıristiyan olan Yahudi ve Müslümanları ifade etmek için kullanılmaktadır. Sadece Müslümanları ifade etmek için Moriscos (cristianos nuevos de moros) Yahudileri ifade etmek için de Converso kelimesi kullanılmaktadır, bkz. Francisco Núñez Muley, A Memorial for the President of the Royal Audiencia and Chancery Court of he City and Kingdom of Granada, Ed.: And Transl. Vincent Barletta, Chicago 2007, s.60, dn.20.

Muley, age, s.23.

Arenal, Los Moriscos, s.508. 
hem de yazdıklarını, hatta ayînlerini bu dille yaptıklarını ifade ederek, şayet, Arap dili gerçekten Katolik imana karşı bir unsur olsaydı, buradaki (Kudüs ve Malta) Hıristiyan filosof ve din adamlarının onu kullanmamalar gerektiğini belirtir. Ayrıca, Deza'nın vicdanına hitap ederek kendisiyle doğulan ve büyülen anadili kimin terk edebileceğini sorar. Yeni Hıristiyanların Kastilyanca dilini öğrenme konusunda istekli olduklarını fakat, tam anlamıyla öğrenmeleri için 3 yıl değil en az 20 yıla ihtiyaç duyulduğunu söyler ${ }^{41}$. Kastilyanca'nın öğrenilmesi konusunda zaman sınırlamasına gidilmesi, Yeni Hıristiyanlar'ın suçlanması ve cezalandırılmasını sağlamaya yönelik bir girişim olarak değerlendirdiğini belirterek, insanların bu zorlamalar nedeniyle yerlerini terk ederek başka diyarlara gittiklerini ve yurtlarını terk edenlerin bir kısmının da eşkiyâlık yaptığını ifade eder ${ }^{42}$.

Gırnata ve civâr bölgelerde yapılan ticâretin alım-satım, senet ve diğer belgelerin Arap diliyle yapılıyor olması Muley'in öne sürdüğü önemli argümanlardan biri olmuştur. Ona göre, Grrnata için önemli bir ticarî faaliyet olan ipek ticâretindeki alım-satım işlemlerinde (ipeğin kilosu, fiyatı, değeri ve oranı) kullanılan isim ve kavramların Arapça olması ve bu isim ve kavramların Kastilyanca'da bulunmaması, Kastilyanca dili ile ticâret yapılmasını neredeyse imkansız hale getirmektedir. Ayrıca, ipekten alınan vergilerin yalnızca Kastilyanca ile yazılması diğer tüm işlemlerin (ipeğin miktarı, aklitesi ve diğer hususlar) ise Arapça yazılmasının karışıklığa neden olacağını, dolayısıyla bu durumun, ticâreti ve vergi tahsilatını olumsuz etkileyeceğini öne sürer ${ }^{43}$.

Muley, Gırnata'nın şehrinin ilk piskoposu olan ve buradaki Mürlümanlar'ın Hıristiyanlaştırılması amacıyla Gırnata'ya gönderilen Hernando de Talavera ile Alpujarra' daki dağ köy ve kasabalarını ziyaret ettiklerinde yağmur duası için insanları duaya davet ettiklerini, dua merâsimi esnasında piskopos Talavera'nın başı açık bir şekilde Moriskolar'ın önünde durarak onların kendi dillerinde, yani Arapça olarak dua etmelerini istediğini ${ }^{44}$ ifade ederek, (bu hadise 1506 veya 1507' de vukû bulmuştu) Arapça' nın Hiristiyan din adamları tarafından dahi yasaklanmadığına delil olarak sunar. Ayrıca, Piskopos Talavera, rahiplerin Arapça öğrenmelerini teşvik ederek,

\footnotetext{
Early Modern Spain, s.108.

Arenal, The Religious, s.55.

Muley, age, s.92-95, 232-234.

Muley, age, s.7.
} 
Hiristiyan akidesinin Moriskolar tarafından hızlıca benimsenmesini ve Yeni Hıristiyanlar'ın günah çıarma ibâdetini Arapça bilen rahipler eşliğinde yapmalarını sağlamaya çalışmıştır. Yine, Talavera, bir Hıristiyan ayînini "...Bayramınız mübarek olsun" diyerek Arapça kelimelerle bitirmiştir ${ }^{45}$.

Muley, Piskopos Talavera'nın aslında geçici bir süreliğine Arapça konuşulmasına izin verdiğinden haberi yokmuş gibi davrandığı görünmektedir. Çünkü Talavera, bir Hıristiyan tarafından beklenen davranışlar listesini sıralarken "...herşeyden daha çok özellikle, konuşmanızda olabildĭği kadar Arapça'yı unutarak ve kendinize unutturarak ve evlerinizde konuşulmasina izin vermeyerek..." diyerek Moriskolar'ın toplumsal entegrasyonunu önermişti. ${ }^{46}$

Memorialda üzerinde önemle durulan hususlardan biri de giyim-kuşama getirilen yasaklardı. Yayımlanan fermanda Mağribî elbiselerin giyilmesi, terziler tarafından bu tarzda elbiselerin dikilmesi, kadınların örtünmesi ve peçe takması yasaklanıyordu. Benzer bir yasak daha önce 29 Temmuz 1513'te ilan edilmiş ve kadınların hala "yüzlerini kapattıkları" belirtilerek, çarşaflarını çıkarmaları için iki yıllık bir geçiş süreci öngörülmüştü. İki yıldan sonra ise çarşaf giymeye devam edenlerin giyim kuşamlarına el konulacak, tekrarı halinde ise kırbaç ve sürgün cezası verilecekti ${ }^{47}$. Araştırmacı Carr'nin de belirttiği gibi XVI. asır İspanyası'nda çarşafa karşı duyulan öfkenin temelinde çarşaf giyen kadınların hayat kadınları olduğu ve gayrı meşrû işler yaptıklarına dair Hıristiyan toplumunda var olan yaygın inanıştı. Nitekim 1523'de Eski Hıristiyanların da çarşaf takması yasaklanmıştı ${ }^{48}$.

Muley ise, Moriskolar'ın giyim-kuşam tarzları ve giydikleri elbiselerin Müslümanlara has olmadığını vurgulamak için örnekler vererek durumu açıklamaya çalışır. Girnata ve civâr bölgelerinde Moriskolar'ın giydikleri elbiselerin bu krallığa özgü "yerel kıyafetler" olduklarını belirterek, bunların Fas (Morocco) ve Türkiye'de giyilen elbiselerden farklı olduklarını söyler. Hatta diğer İslâm beldelerinde de elbiseler konusunda farklılıklar mevcuttur; Fas'daki giyim, Cezâyir'deki (Tlemcen) giyim gibi, Tunus'daki Fas'daki gibi değildir. Aynı şey Türkiye ve diğer krallıklardaki giyimler için de söz konusudur. Şayet, Muhammed'in (s.a.v.) dini belirli elbiseleri giymeyi

\footnotetext{
5 Arenal, The Religious, s.501.

46 Carr, age, s.113.

47 Carr, age, s.122.

48 Carr, age, s.122-123.
} 
öngörseydi, İslâm dünyasının her tarafında aynı şekildeki elbiselerin giyilmesi lazımdı. Muley, elbise konusunda iknâ edici başka bir argüman daha kullanır; Suriye' de ve Mısır'da Hıristiyan din adamları ve bu sınıftan olmayan Hıristiyanların Türk tarzında giyindiklerini; başlarını sardıklarını, boydan boya kaftan giydiklerini, Arapça ve Tükçe konuştuklarını, İspanyolca veya Latince konuşmayı bilmediklerini ve bunların halen Hıristiyan oldukları örneğini vererek, Pedro de Deza'yı etkilemeye çalışmıştır.

Muley, giyim-kuşam değişiminin ekonomik boyutuna da değinerek, Gırnata ve civâr bölgelerde 200 binden fazla kadının yaşadığını (başka bir anlatımda ise; 50 bin kadın olduğu ve bu kadınların her birinin ise iki kız çocuğu olduğu düşünüldüğünde 150 bin kadına tekâbül ettiği, bunlardan $4-5$ bini hariç diğerlerinin ancak rehin vererek yeni elbiseleri alabilecekleri belirtiliir ${ }^{49}$ ), bunların yeni elbiseler alması durumunda sözkonusu parayı bulamayacaklarını, Kastilya eteği, şalı, terliği ve şapkasını alacakları paralarının olmadığını belirtir. Ayrıca, 3 milyondan fazla para harcanarak yaptırılan mevcut elbiselerin terk edilmesi ciddî bir ekonomik israftır ve bu sektörde çalışan tüccarların, simsarların, kuyumcuların ve diğer şahısların işlerini kaybetme tehlikesiyle yani, bir işsizlik sorunuyla karşılaşacaklardır ${ }^{50}$. Muley, Girnata ve civâr bölgelerde de kılık-k1yafet konusunda bir tutarlığın olmadığı görüşündedir. Ona göre; halk temiz, kısa, şık ve ucuz elbiseler aramakta, bazen bir dukalık elbiseler giymekte, düğün elbiselerini korumakta ve bu elbiseleri üç-dört nesil korumaktan zevk almaktadır. Dolayısıyla, halkın bu geleneğini bırakmasının istenmesinde herhangi bir fayda görmediğinin altını çizmektedir ${ }^{51}$. Muley, yaşlı insanlara sorulduğunda daha önce giyilen elbiselerin şimdikinden farklı olduklarını hatırlayacaklarını ifade ederek, elbise konusunda bir değişim yaşandığını da vurgular ${ }^{52}$. Ayrıca, devletin önemli bir gelirinin Moriskolar'ın yaptıkları ipek, inci ve altın ticâretinden geldiğinin belirtir.

Kadınların yüzlerinin örtünmesine karşı çıkılmasına bir anlam veremediğini ifade eden Muley, kadınların yüzlerini açmaları durumunda, erkeklerin günaha daha meyilli olacaklarını ve çirkin kadınların bekâr kalma problemiyle karşılaşılacağını belirtir. Ona göre

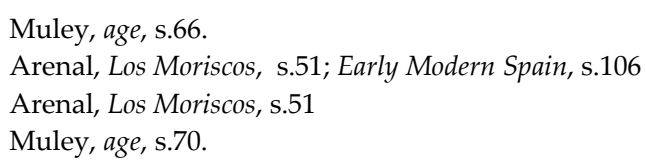


kadınların yüzlerini örtmeleri tamamen "tanınmama" durumuyla ilgilidir. Dinî herhangi bir boyutu yoktur. Nitekim, Katolik Kral Fernando, ağır baskı altında da olsalar Hıristiyanların, Morisko kadınların örtüsünü açmaya teşebbüs etmelerini yasaklamıştır. Muley, bu krallıkta yaşayan kadınların örtü sebebiyle neden rahatsız edildiklerini sorar ${ }^{53}$.

Şarlken döneminde Gırnata Başkomutanı Tendilla Markizi'nin İspanya sarayına gönderdiği bir mektupta “...majestelerinin Morisko kıyafetlerini neden yasakladığıı anlayamadığııı..." belirterek "...Tanrı'ya yemin ederim ki, krallık bir yıl içinde, kıyafet değişimi ve satışlarından kazandığı, bir milyon dukadan daha fazlasını kaybedecektir..." diyerek kıyafet yasağına karşı çıkmıştı ${ }^{54}$.

Çarşaf ve peçe takılmasının yasaklanması kanûnlar yoluyla Müslümanlar'ın en mahrem alanlarına İspanyol yönetiminin yaptığı saldırıların bir parçasıydı. Bu yasakla, bireysel mahremiyet alanı toplumsal alana taşınarak, toplumsallaştırılarak içinin boşaltılması, değersizleştirilmesi amaçlanmıştır ${ }^{55}$.

Memorialda üzerinden durulan önemli hususlardan bir diğeri de hamamların yasaklanmasıdır. Aslında hamamlar XV. asırdan sonra Avrupa ve İspanya' da yasaklanmıştı. Bu yasağın gerekçeleri arasında, vücud'un direncini düşürdükleri, fahişelik ve ahlaksızlık mekânları olduğu ve Müslümanlar'a özgü mekânlar oldukları yer almıştır ${ }^{56}$. Çıkarılan fermanda (Premática) "... şahsî ve umuma açık bütün hamamların yıkılması..." emredilmekteydi. Muley, hamamların toplumun temizlik ihtiyacının bir sonucu olarak var olduklarını, herhangi bir dinî refaransının olmadığını ifade eder. Ona göre; hamamların Moriskolar'ın gizlice ibâdet ettikleri ve İspanyol yönetimine karşı toplantıların yapıldı̆̆ı mekânlar olarak düşünülmesi tamamen yanlıştır. Çünkü, Moriskolar'ın ibâdet mahalleri için gerekli olan temiz mekânlardır, dolayısıyla, bu yerler hamamlar olamaz. Hamamlar, umuma açık ve çoğu zaman Hıristiyanların kullandıkları yerler olmaları sebebiyle gizli toplantıların mekânı da olmazlar. "Kir dolu havuza" benzettiği hamamlara halk çeşitli hastalık ve yaralar sebebiyle gitmekte, en çok da balıkçlar, demirci, nalbantçı, kömür satıcıları, yă̆ satıcıları, kasaplar, iplikçiler (iplik yapıcıları),

\footnotetext{
Early Modern Spain, s.108.

Carr, age, s.123.

Carr, age, s.123.

Carr, age, s.87.
} 
mezbahanelerde çalışan dericiler, ve [mezbahanelerin] dışında çalışanlar, kamusal septik tanklarda çalışanlar, cadde ve evlerde biriken pislikleri kaldıran lağımcılar, kirli evlerde ve gübre işinde çalışanlar ile buna benzer işlerde çalışanlar hamamları kullanmaktadır ${ }^{57}$. Hamamların bir dönem Kastilya'da yasaklanmış olması, savaşçıların savaşma kabiliyetlerini zayıflattı̆̆ı inancıyladır, şuanda da herhangi bir savaş sözkonusu değildir. İnsanların kendi evlerinde, dere ve çaylarda yıkanmalarına da mani olunursa, temizlik ihtiyacının nasıl karşılanacağını sormaktadır ${ }^{58}$. Muley'in hamamların yıkılmasını engellemek için öne sürdüğü gerekçeleri, XIII. yy'da İspanya'nın Zorita kasabasındaki uygulamalar desteklemektedir. Belki de hiçbir Morisko'nun yaşamadığı bu kasabada hamamlar, Salı, Perşembe ve Cumartesi günleri erkeklere, Pazartesi ve Çerşamba günleri kadınlar, Cuma ve Pazar günleri ise Yahudiler'e açıkt ${ }^{59}$.

Fakat, öne sürülen tüm gerekçelere rağmen, Gırnata'daki hamamların kapatılması ve yıkılmalarını önüne geçilemeyecektir. Şayet, herhangi bir kimse bu hamamları evinde veya başka bir yerde muhafaza etmeye kalkıp kullanırsa, 50 gün zincirli hapis, 100 bin maravidi para ve 2 yıl sürgün cezasıyla, ikinci defa bu suçu işlemesi durumunda cezaya iki katına çıkarılacak, üçüncü defa suçu tekrar işlemesi durumunda ise malının yarısına el konulacak ve 5 yıl kürek mahkûmiyetiyle cezalandırılacakt ${ }^{60}$.

$Z_{\text {Zambra }}{ }^{61}$ ve Leilalar (oyun ve şarkılarla şenlik), Katolik dine aykırı olmamasına rağmen Cuma ve bayram günlerinde yasaklanması Muley'in üzerinde önemle durduğu konulardan biriydi. Muley, bunların Moriskolar'ın kültürel bir değeri olarak anlaşılmasına anlam veremediğini, bu seramonilerin kendilerini Hıristiyanlıktan uzaklaştırmadığını ve Hıristiyan olmalarını engellemediğini ifade eder. Kaldı ki, iyi bir Morisko'nun bunları yapmasıyla karşılaşılmadığını, İslâm fakîhlerinin ise; zambralar oynamaya, şarkılar söylenmeye başlandığında, o mekânı derhal terk ettiklerinin bilindiğini söyler. Şayet, dinî bir seranomi olsaydı, hem Afrika'da hem de Türkiye'de olmaları gerekirdi, dolayısıyla zambra ve leilalar bu krallığa

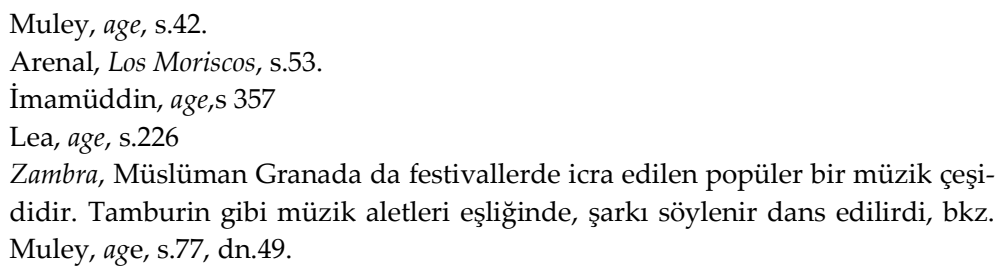
didir. Tamburin gibi müzik aletleri eşliğinde, şarkı söylenir dans edilirdi, bkz. Muley, age, s.77, dn.49. 
ait seranomilerdir. Muley'e göre, bu seranomilerin ortadan kaldırılması gerekiyorsa bu işi zamana bırakmak gerekmektedir. Çünkü, kutsal Corpus Christi ${ }^{62}$ gününde yapılan ayinlere/törenlere gün geçtikçe katılımlar artacak ve zamanla zambra ve leilalar unutulacaktır63. Yine Muley, Hernando de Talavera zamanından enstrümental eşliğinde zambraların çalındığını ve bu konuda Talavera'nın herhangi bir yasaklama yoluna gitmediğini, Hıristiyanların kutsal gün ve ayînlerinde bunların çalındı ğının ifade ederek bu yasağın anlamsızlığını belirtmeye çalışır ${ }^{64}$.

Cuma, Pazar ve bayram günlerinde evlerin kapılarının açık bırakılması (Katolik müfettişlerin, Moriskolar'ın namaz kılıp kılmadıklarını teftiş maksadıyla) zorunluluğu, Muley'in üzerinde durduğu önemli noktalardan biridir. Muley, Moriskolar'ın gizlice ibâdet etmelerinin önlerinde ciddi bir engelin bulunmadığını (yani, geceleyin de ibâdet edebilecekleri) dolayısıyla, kapıların açık tutulmasının işe yaramayacağını, bu durumun hırsızlara yarayacağını ve kadınlara tecâvüz girişimlerinin önünü açacağını belirtir ${ }^{65}$. Kapıların kapalı tutulmasının Katolik İmana karşı bir eylem olmadığını vurgular.

Muley, "Kına (henna) yakmanın" yasaklanması üzerinde de durur. Ona göre kına ${ }^{66}$ bu krallıkta (Girnata) yer alan insanların temizlik maksadıyla vücud ve saçlarına sürdüğ̈ ve banyoya girdikleri zaman kullandıkları bir temizlik maddesidir. Müslümanlara has olmayan kına ile insanlar temizlenmektedir. Sabunla birlikte kullanıldığında, erkek, kadın ve çocukların derilerine sürüldüğünde uyuz hastalığını yok ederek onları iyileştirir. Yine kadınlar saçlarını kına ile renklendirir ve başağrısına mubtela olduklarında kına ile şifa bulurlar. Sanatçılar el ve ayaklarını temizlemek, özellikle, düğünlerde hoş ve çekici görünmek için kına yakarlar. Muley, 1518'de Guadix piskoposu Don Pedro de Guavera'nın krallıktaki kadınların kına yakmalarını engellemek maksadıyla onların başlarını traş etmele-

62 Corpus Christi Günü: Latince' de İsa'nın bedeni anlamına gelir. Katolik yortusudur. (a.s.)

63 Arenal, Los Moriscos, s.52.

64 Muley, age, s.223; Carr, age, s.49.

65 Arenal, Los Moriscos, s.53; Early Modern Spain, s.107.

66 Kına ile ilgili olan kısımların ki-bunlar XVIII. asırda Alhamra arşivinde keşfedildi, Muley'e ait olduğu şüphelidir veya şayet bu kısım yer alıyorsa Muley bu kısmı Deza'ya yazdığı mektuba almayı düşünmemiştir, Muley, age, s.21. 
rini emrettiğini fakat, bu girişimin Senyörler tarafından engellendiğini ifade ederek, Hernando de Talavera'nın da kınayı yasaklamadığını belirtir ${ }^{67}$.

Mağribî isim ve soyisimlerin terk edilmesinin (kabile ismine atıf yapılan İbn ${ }^{68}$ gibi) istenmesi Muley'in açılama yapmak zorunda kaldığı bir diğer husustur. Ona göre; eski soyisimler bir insanı, diğerinden ayırmaya yardımcı olmaktadır. onların yitirilmesi durumunda toplumsal hafızanın kaybolacağı ve bu durum kimsenin faydasına olmayacaktır. Kaldı ki Katolik Krallar'ın dahi soyisimleri yasaklama yoluna gitmemeleri, bu krallıkta yer alan kişilerin hem kendi soykütüklerini hem de fâtihlerin (conquistadorlar) hatıralarını korumalarına yardımcı olmuştur ${ }^{69}$. İsimler konusunun ekonomik boyutunun da varolduğunun altını çizen Muley, vergi evraklarının bu soyisimlere (lakab/künye) göre düzenlendiğini ileri sürerek bunların kullanılmaması durumunda, faturaların kimler adına düzenleneceğinin problem olacağını ve dolayısıyla vergilerin toplanmasında sıkıntıların yaşanacağını belirtir ${ }^{70}$.

Memorialda yer alan konulardan biri de, Moriskolar'ın siyahî köle sahibi olmalarıyla ilgili yasaklayıcı maddeye olan itirazdı. Çıkan kanûnda, Moriskolar'ın sahip oldukları ve genel olarak Kuzey Afrika'dan getirilen bu kölelerin Gırnata'yı terk etmeleri istenmekteydi. Bu tarihten sonra hiçbir Morisko köle sahibi olamayacaktı. Katolik yönetim her geçen gün sayıları artan bu kölelerin Müslüman olmasından ve olası bir isyana kalkışmasından korkmaktayd ${ }^{71}$. Muley, 20 binden fazla kölenin bulunduğu Girnata ve civârında, kölelerle ilgili durumun daha önce Tuleytûla'da (Toledo) ele alındığını ve bunların büyük bir kısmının vatandaş statüsüne alındığından bahsederek, 100 kişiden fazla köle sahibi olunmasına

\footnotetext{
Arenal, Los Moriscos, s.52; S.16.

8 Muley, isimler konusunda Muley, isimler konusunda dört kalıba işaret etmektedir: Künye: ilk çocukluk ismine mesela Ebû Ali Muhammed (Ali'nin babası olan Muhammed gibi), Nesep: sülale, kökene işaret eder. Muhammed b. Ali b. Ahmet gibi, Lakap: kişinin mesleği ile bağlantısını gösteren bağ (Muhammed el-Katip gibi, yani katip Muhammed gibi), Nisbet: Kişinin nereli olduğuna işaret eder, Muhammed el-Fezî (Fez'li Muhammed gibi), 16. Asrın Granadasında bütün bunlar birlikte kullanılırdı, mesela Ebû Ali Muhammed b. Muhammed el Fezî gibi, Muley, age, s.88, dn.68.

69 Arenal, Los Moriscos, s.54.

70 Muley, age, 105.

71 Muley, age, s.45.
} 
lisans verilmediğini belirtir ${ }^{72}$. Ona göre Moriskolar'ın da en az $\mathrm{H}_{1}-$ ristiyanlar kadar hizmete ihtiyaçları vardı ve dolayısıyla kölelerinin ellerinden alınmasına ve köle sahibi olmalarına engel olunmasının hiçbir gerekçesi olamazd.

\section{Sonuç}

Memorial, XVI. asrın ikinci yarısında, Endülüs Müslümanları (Moriskolar) için verilecek nihâi sürgün kararını (1609-1614) -Moriskolar için "İspanya'nın Firavunu'ndan" kaçıştı ${ }^{73}$ - durdurmaya yönelik sonuçsuz kalan en etkili çaba olmuştur. Francisco Núñez Muley'in de ifade ettiği gibi kendilerini "Kastilya veya Andalucia Horistiyanları" olarak gören Moriskolar'ın Katolik İspanyol yönetimi ile süreç içerisindeki (1492-1567) ilişkilerine 1şık tutmakta, Moriskolar'ın bu süreçte yaşanan olumlu-olumsuz olaylara bakışını yansıtmaktadır.

Memoriala yansıyan ifadelere yakından bakıldığında hem bir arzuhâl hem bir ihtarnâme hem de bir izahatnâme olarak değerlendirilebilir. Francisco Núñez Muley, çıkan yasaların ( $L a$ nueva premática) uygulanması durumunda ortaya çıkabilecek sorunlara (bilhassa sosyo-ekonomik) işâret ederek Pedro de Deza'nın "gözünü açmasını" ve krallığı bekleyen tehlikeleri görmesini isterken, Moriskolar'ın Gırnata krallığının en sadık vatandaşları olduğunun altını çizerek, tek gayelerinin İspanya kralına ve krallığına sonsuza dek hizmet etmek olduğunu belirtir. Yasakların, Gırnata ve civâr bölgelerinde yaşayan vatandaşların örf ve adetlerine aykırı olduğunu, sahip oldukları sosyo-kültürel değerlerin dinden (İslâm) değil, yerel anlayıştan kaynaklandıklarını sık sık vurgular.

Francisco Núñez Muley, memorialda öne sürdüğü tezini doğrulamak için bazen ilginç örnekler vermektedir. Mesela, hamama gitmenin ve kına yakmanın Hıristiyan kültürünün bir parçası olduğuna dair yaklaşımı böyledir. Halbuki, Endülüs coğrafyacısı İbrahim b. Yakup'un Galicialılar için belirttiği gibi İspanyol kültüründe, genelde, senede bir veya iki defa defa soğuk su ile yıkanmak sözkonuydu ve kıyafetlerini eskiyene kadar yıkamıyorlardı. Bunun sebebi ise terliyken üzerlerinde biriken kirin bedenlerini yumuşattığ 1 inancıyd $1^{74}$. Hiristiyan kadın ve erkeklerin yaygın olarak kına kullandıklarına dair bir veri de bulunmamaktaydı.

72 Arenal, Los Moriscos, s.54.

73 Carr, age, s.361.

74 Carr, age, s.37. 
Hem Madrid sarayı, hem de Girnata Kraliyet Yüksek Mahkemesi bu mektuba/memorial duyarsız kalmıştır. Mármol, bu mektuba karşı resmî anlamda bir reaksiyon olduğunu kaydetse de, bu reaksiyonlar memorialdan 30 yılı aşkın bir süre sonra yapılmıştır ${ }^{75}$. Ayrıca, Mármol, memorialı kısaltarak kitabına almış bazı kısımları ihmâl etmiş veya atlamıştır. Bu durum onun inanç ve diğer düşünceleri sebebiyledir ${ }^{76}$.

Muley, Moriskolar'a getirilen yasakların er veya geç "krallığın ve yerlilerinin yıkımına" yol açacağını ifade ederken, aslında, kendi çaresizliklerini de ifade etmiş oluyordu. Ona göre; Moriskolar bu yaptırımlar karşısında "uyum sağlamaktansa, ölmeyi ya da bu yük ve cezalar altında acı çekmeyi yeğlerlerdi"77. Nitekim çok geçmeden Gırnata ve çevresini alev gibi saracak bir isyan başlayacak (1568-1570) ve bu isyan İspanyol toplumu ve devletinin maddî ve manevî imkanlarını ciddi anlamda tüketecektir.

\section{Kaynakça}

Arenal, Mercedes Garcîa, Los Moriscos, Universidad de Granada, Granada 1996.

Arenal, Mercedes García, "The Religious Identity of the Arabic Language and he Affair of the Lead Books of the Sacromonte of Granada", Arabica, 56 (2009), s.498-

Bauman, Zgmunt, Postmodernlik ve Hoşnutsuzlukları, Çev.: İsmail Türkmen, Ayrıntı Yayınları, İstanbul 2013.

Bilgin, Feridun, Nasrîler (Benî Ahmer) Sonrasında Endülüs'teki Müslümanlar (Moriskolar), Yayımlanmamış Doktora Tezi, Marmara Üniversitesi Sosyal Bilimler Enstitüsü, İstanbul 2010.

Bleda, Jaime, Coronica de Los Moriscos de España, Universitad de Valencia, Valencia:, 2001.

Burín y Sandoval, Antonio Gallego -Alfonso Gâmir, Los moriscos del reino de Granada según el Sínodo de Guadix de 1554, Universidad de Granada, Granada 1996.

Carr, Matthew, Kan ve İman, trc.: Regaip Minareci, Alfa Yayınları, İstanbul 2015.

Carvajal, Luis de Mármol, Historia de Rebellion y Castigo de los Moriscos del Reino de Granada, I-II, Madrid 1797.

Contreras y Muñoz, Rafael, “Nuevos Datos Sobre la Guerra y la Expulsión de los Moros", Revista de España, LXVIII (1879): 185-209.

\footnotetext{
García, agm, s.4

Muley, age, s.16

Carr, age, s.212.
} 
Epalza, Míkel de, “La Voz Oficial De Los Musulmanes Hispanos, Mudejares y Morıscos, A Sus Autoridades Cristianas: Cuatro Textos, En Árabe, En Castellano y En Catalán-Valenciano", Sharq al-Andalus, 12 (1995).

Early Modern Spain, (Ed. Jon Cowans), University of Pennsylvania, Philadelphia 2003.

Fernández, Javier Castillo, La Historiografía Española del Siglo XVI: Luis del Mármol Carvajal y Su Historia del Rebelión y Castigo de Los Moriscos del Reino de Granada. Análisis Histórico y Estudio Crítico, Editorial de la Universidad de Granada, Granada 2014.

Foulché-Delbosc, Raymond, "Memorial de Francisco Núñez Muley", Revue Hispanique, Paris, VI (1899): 205-239.

García, Carlos Javier Garrido, “Colaboracionismo mudéjar-morisco en el Reino de Granada. El caso de la Diócesis de Guadix: Los Abenaxara (1489-1580)", MEAH, Sección Árabe-Islam, 48 (1999).

Harvey, Leonard Patrick, "Capitulations of Granada”, Çev.: Teofilo Ruiz, Philadelphia 1997, s. 344-350.

Harvey, Leonard Patrick, Muslims in Spain, 1500 to 1614, The University of Chicago Press, London 2005.

http://lema.rae.es/drae/?val=farda) (25.03.2015).

İmamüddin, S.Muhammed, Endülüs Siyasi Tarihi, terc.: Yusuf Yazar, Rehber Yayıncilik, Ankara 1990

Jose Maria Martin Ruiz, “Politica y Moral en El Siglo de Oro: El Memorial del Morisco Francisco Nuñez Muley", Baetica. Estudios de Arte, Geografía e Historia, 17 (1995).

Lea, H.Charles, İspanya Müslümanları Hıristiyanlaştırılmaları ve Sürülmelerleri, Çev.: Abdullah Davudoğlu, İnkılap Yayınları, İstanbul 2006

Mata, M. ${ }^{\mathrm{a}}$ Jesús Rubiera, "La Familia Morisca de Los Muley-Fez, Príncipes Meriníes e Infantes de Granada”, Sharq al-Andalus, 13 (1996).

Muley, Francisco Núñez, A Memorial for the President of the Royal Audiencia and Chancery Court of he City and Kingdom of Granada, Ed.: And Transl. Vincent Barletta, Chicago 2007.

Özdemir, Mehmet, Endülüs Müslümanları (siyasî tarih), Türkiye Diyanet Vakfı Yayınları, Ankara 2012.

Özdemir, Mehmet, "Moriskolar", DİA, XXX, 288-191.

Rosell, Don Cayetano, Histariadores de Sucesos Particulares, M. Rivadeneyra, I, Madrid 1858.

Sanjuan, Joaquin G1l, "Presion Material Sobre Los Moriscos Andaluces", Baetica. Estudios de Arte, Geografía e Historia, 3, 1980, s.189. 


\section{Mílel VE NiHAL}

inanç, kültür ve mitoloji araştırmaları dergisi

Cilt/Volume: 12 Sayı/Number: 1 Ocak - Haziran / January - June 2015

ISSN: 1304-5482

Bu dergi uluslararası EBSCO HOST Research Databases veri indeksi ve

TÜBİTAK-ULAKBİM Sosyal ve Beşeri Bilimler Veri Tabanı tarafından taranmaktadır.

\section{Sahibi / Owner}

Milel ve Nihal Eğitim, Kültür ve Düşünce Platformu Derneği adına Şinasi Gündüz

$$
\begin{gathered}
\text { Yazı İşleri Sorumlusu / Legal Representative } \\
\text { Yasin Aktay }
\end{gathered}
$$

Editör / Editor

Şinasi Gündüz

Editör Yrd. / Co-Editor

Cengiz Batuk

Hakan Olgun

\section{Sayı Editörü / Editor of Issue}

Feridun Bilgin

Yayın Kurulu/ Editorial Board*

Alpaslan Açıkgenç, Ayaz Akkoyun, Yasin Aktay, Mahmut Aydın,

Cengiz Batuk, Şinasi Gündüz, İbrahim Kayan, Hakan Olgun, Necdet Subaşı, Burhanettin Tatar

\section{Danışma Kurulu/Advisory Board*}

Baki Adam (Prof. Dr., AÜ); Mohd. Mumtaz Ali (Prof. International Islamic U. Malezya); Adnan Aslan (Prof.Dr., Süleyman Şah Ü.); Kemal Ataman (Doç.Dr., Uludağ Ü.); Mehmet Akif Aydın (Prof. Dr., Marmara Ü.); Yılmaz Can (Prof. Dr., OMÜ); Ahmet Çakır (Doç. Dr., OMÜ); Mehmet Çelik

(Prof. Dr., Celal Bayar Ü.); Waleck S. Dalpour (Prof. University of Maine at Farmington); İsmail

Engin (Dr., Berlin); Cemalettin Erdemci (Prof.Dr. YYÜ); Tahsin Görgün (Prof.Dr., 29

Mayıs Ü.) Ahmet Güç (Prof.Dr., Uludağ Ü.); Recep Gün (Doç. Dr., OMÜ); Ö. Faruk Harman

(Prof.Dr., Mar.Ü.); Erica C.D. Hunter (Dr., Cambridge U.); Mehmet Katar (Prof. Dr., A.Ü.);

Mahmut Kaya (Prof. Dr., İ.Ü.); Sadık Kılıç (Prof.Dr., Atatürk Ü..); Şevket Kotan (Y.Doç.Dr., İ.Ü.);

İlhan Kutluer (Prof.Dr., Mar. Ü.); George F. McLean (Prof. Catholic Univ., Washington DC); Ahmet Yaşar Ocak (Prof. Dr., Hacettepe Ü.); Jon Oplinger (Prof. University of Maine at Farmington); Ömer

Özsoy (Prof.Dr., Frankfurt U.); Roselie Helena de Souza Pereira (Mestre em

Filofia-USP; UNICAMP Brasil); Ekrem Sarıkçığlu (Prof.Dr., SDÜ); Hüseyin Sarıoğlu (Prof.Dr.,

IÜ); Bobby S. Sayyid (Dr. Leeds U.); Mustafa Sinanoğlu (Prof.Dr., 29 Mayıs Ü.); Mahfuz Söylemez

(Prof.Dr. İÜ); Necdet Subaşı (Y.Doç.Dr., DİB); Bülent Şenay (Prof.Dr., UÜ); İsmail Taşpınar

(Prof.Dr. Mar.Ü.); C. Sadık Yaran (Prof.Dr., OMÜ); Ali Murat Yel (Prof.Dr., Fatih Ü.); Hüseyin Yılmaz (Doç.Dr., YYÜ); Ali İhsan Yitik (Prof. Dr., DEÜ)

$$
\text { * Soyadına göre alfabetik sıra / In alphabetical order }
$$

\section{Kapak ve Sayfa Tasarımı / Cover \& Page Design} İnan $\mathrm{Avc1}$

\section{Baskı / Publication}

Ladin Ofset - İstanbul, Ekim 2015

2.Mat. Sit. 3 NB 15 Topkapi İstanbul / İsmail Tüz 02125012418

Yönetim Yeri / Administration Place

Milel ve Nihal Eğitim, Kültür ve Düşünce Platformu Derneği

Fevzipaşa Cad. Şehit Mehmet Sarper Alus Sok. No: 5, K.: 3, Tel: (0212) 5339731 Fatih/İstanbul www.milelvenihal.org e-posta: dergi@milelvenihal.org

Milel ve Nihal yılda iki sayı olarak altı ayda bir yayımlanan uluslararası hakemli bir dergidir.

Milel ve Nihal' de yayımlanan yazıların bilimsel ve hukuki sorumluluğu yazarlarına aittir. Yayım dili Türkçe ve İngilizce' dir. Yayımlanan yazıların bütün yayın hakları Milel ve Nihal'e ait olup, yayıncının izni olmadan kısmen veya tamamen basılamaz, çoğaltılamaz ve elektronik ortama taşınamaz. Yazıların yayımlanıp yayımlanmamasından yayın kurulu sorumludur. 


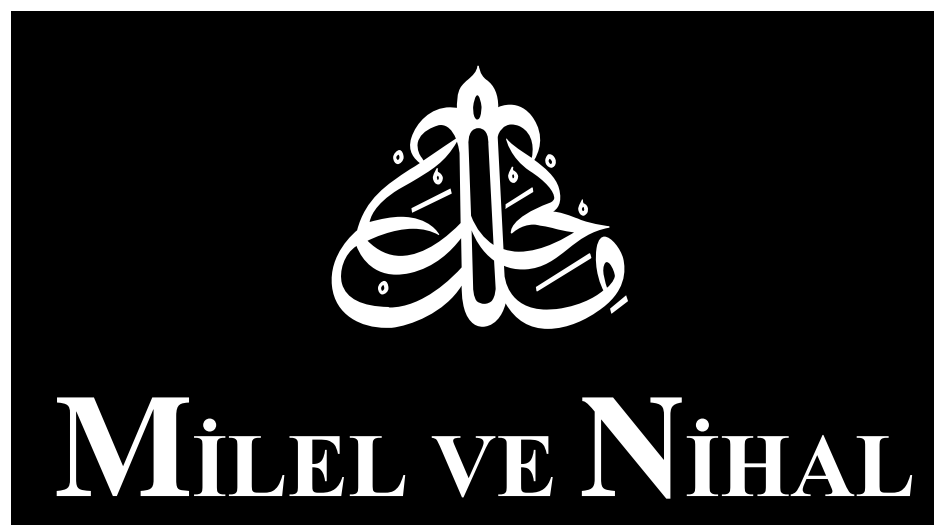

inanç, kültür ve mitoloji araştırmaları derogisi

ISSN: 1304-5482

ENDÜLÜS

Cilt/Volume: 12 Sayı/Number: 1

Ocak - Haziran / J anuary - June 2015 
